\title{
PENILAIAN SIKAP SEBAGAI DAMPAK PENGIRING PEMBELAJARAN PRAKTIKUM KIMIA
}

\author{
Ni Putu Nanik Puspita Sari ${ }^{1}$, I Ketut Sudiana², \\ Universitas Pendidikan Ganesha \\ Singaraja, Indonesia \\ e-mail: nanik.puspita.sari@undiksha.ac.id ${ }^{1}$,sudiana@undiksha.ac.id²,
}

\begin{abstract}
Abstrak
Penelitian ini bertujuan untuk mendeskripsikan dan menjelaskan penilaian sikap sebagai dampak pengiring pembelajaran praktikum kimia. Penelitian ini termasuk jenis penelitian fenomenologi dengan pendekatan kualitatif. Subjek dalam penelitian ini adalah rencana pelaksanaan pembelajaran (RPP), guru kimia, siswa, waka kurikulum, pengawas eksternal dan pedoman penilaian sikap. Teknik pengumpulan data dengan cara wawancara, observasi, dan studi dokumen. Uji keabsahan yang digunakan dalam penelitian ini adalah triangulasi sumber dan triangulasi metode. Teknik analisis data yang digunakan adalah reduksi data, penyajian data, dan penarikan kesimpulan. Hasil penelitian ini yaitu, perencanaan penilaian sikap, guru merencanakan penanaman nilai karakter serta melakukan penilaian sikap yang terlihat pada RPP yang disusun oleh guru. Pada pelaksanaan penilaian sikap, guru melakukan penanaman sikap sesuai yang dirancang pada RPP. Nilai karakter yang terdapat pada irisan dari sikap sosial, pendidikan karakter dan softskills guru sudah menanamkan semua nilai karakter. Pada saat penilaian sikap guru hanya menilai sikap siswa menggunakan penilaian jurnal berdasarkan hasil observasi guru serta guru hanya menilai tiga sikap yang ditanamkan yauu rasa ingin tahu, jujur, disiplin dan tanggungjawab. Pengawasan penilaian sikap dilakukan oleh pengawas sekolah dan waka kurikulum pada tugasnya sebagai supervisi melakukan pengecekan administrasi guru termasuk penilai sikap yang dirancang guru. Pada penilaian sikap terdapat keluhan penilaian sikap, pengawas mengantisipasinya dengan melakukan workshop agar tidak terjasi kesalah dalam melakukan penilaian sikap.
\end{abstract}

Kata kunci: penilaian sikap, pendidikan karakter dan dampak pengiring.

\begin{abstract}
This study aims to describe and explain the attitude assessments as the impact of accompanying the chemical practicum learning. This study was a qualitative research with a phenomenological approach. The subjects in this study were the lesson plans (RPP), chemistry teachers, students, deputy headmaster of the curriculum, external supervisors and attitude assessment rubric. The data collection methods that used in this study were interview, observation and document studies. The validity test used in this study were source triangulation and method triangulation. The data analysis techniques used were data reduction, data presentation, and conclusion. The results of this study were planning the attitude assessment, the teacher planned to embed the character values and conduct an attitude assessment which shown on the lesson plan that prepared by the teacher. In the implementation of the attitude assessment, the teacher implements the embedded attitudes according to the design in the lesson plan. The character values that contained in each of social attitudes, character education and soft skills
\end{abstract}


have been embedded by the teachers. On the attitude assessment phase, the teacher only assessed the student attitudes by using journal assessment based on the results of the teacher's observation and the teacher only assesses the three attitudes that embedded those were curiosity, honesty, discipline and responsibility. Supervision of the attitude assessments was carried out by school supervisors and deputy of the curriculum in their duties as supervisors to check the administration of the teacher including attitude assessors designed by the teacher. On the attitude assessment there was a complaint of the attitude assessment, the supervisor anticipated it by conducting a workshop to not get caught up in making an attitude assessment.

Keywords: attitude assessment, character education and impact accompaniment.

\section{PENDAHULUAN}

Berdasarkan Perpres Nomor 87 Tahun 2017 tentang Penguatan Pendidikan Karakter pasal 1 ayat 1 dijelaskan bahwa Penguatan Pendidikan Karakter (PPK) adalah gerakan pendidikan dibawah tanggung jawab satuan pendidikan. PPK bertujuan untuk memperkuat karakter peserta didik melalui harmonisasi olah hati, olah rasa, olah pikir, dan olah raga dengan pelibatan kerjasama antara satuan pendidikan, keluarga, dan masyarakat sebagai bagian dari Gerakan Nasional Revolusi Mental (GNRM). Permendikbud Nomor 20 Tahun 2018 tentang Penguatan Pendidikan Karakter (PPK) dijelaskan bahwa PPK dilaksanakan dengan menerapkan nilai-nilai pancasila dalam pendidikan karakter yang meliputi sikap religius, jujur, toleran, disiplin, bekerja keras, kreatif, mandiri, demokratis, rasa ingin tahu, semangat kebangsaan, cinta tanah air, menghargai prestasi, komunikatif, cinta damai, gemar membaca, peduli lingkungan, peduli sosial, dan bertanggung jawab.

Permendikbud Nomor 22 Tahun 2016 menyatakan bahwa prinsip pembelajaran harus meningkatkan dan menyeimbangkan antara keterampilan fisikal (hardskills) dan keterampilan mental (softskills). Hal tersebut didukung dengan hasil penelitian Ratnawati (2016) bahwa terdapat kontribusi positif antara pendidikan karakter terhadap soft skills. Pendidikan karakter siswa baik maka diikuti dengan soft skills yang baik.

Kemendiknas (2010) menjelaskan bahwa persoalan budaya dan karakter bangsa kini menjadi sorotan tajam masyarakat. Hal tersebut dibuktikan dengan adanya korupsi, kekerasan, kejahatan seksual, perkelahian masa, kehidupan ekonomi yang konsumtif, seta kehidupan politik yang tidak produktif menjadi topik pembahasan hangat dimedia masa, seminar, dan berbagai kesempatan.

Permendikbud No. 81A tahun 2013 menyatakan bahwa kurikulum 2013 mengembangkan dua modus pembelajaran yaitu pembelajaran langsung dan tidak langsung. Pembelajaran langsung dan tidak langsung memiliki dampak intruksional dan dampak pengiring. Pada mata pelajaran PABD dan PPKn dibelajarkan secara langsung maupun tidak langsung. Pembelajaran tidak langsung (nurturant effect) berkenaan dengan implemantasi nilai dan sikap. Pengembangan sikap, moral dan prilaku dilakukan oleh seluruh guru mata pelajaran termasuk mata pelajaran kimia. Hal ini didukung dengan hasil penelitian Adawiah menyatakan bahwa, banyak guru yang beranggapan bahwa pendidikan karakter tugas dari guru mata pelajaran agama dan PPKn. Seharusnya pendidikan karakter merupakan tugas dari guru semua mata pelajaran, karena mengajarkan nilai moral yang berdampak pada kehidupan (Adawiah, 2016).

Mata pelajaran kimia sangat terkait dengan sinergis antara pemaparan konsep di kelas dengan kegiatan praktikum di laboratorium untuk menentukan keberhasilan dan kebermaknaannya (Mariati dan Riska, 2012).Pada proses pembelajaran kimia tidak terlepas dari kegiatan pengamatan dan eksperimen yang sangat membutuhkan sikap tertentu seperti tanggung jawab dan kejujuran ketika mengumpulkan dan menganalisis data. Oleh karena itu, guru sangat dianjurkan untuk dapat mengembangkan instrumen penilaian sikap peserta didik selama pembelajaran kimia berlangsung (Nufus, dkk. 2017).

Kemendikbud (2017) menyatakan bahwa penilaian sikap merupakan bagian dari pembinaan dan penanaman atau pembentukan sikap spiritual dan sikap sosial peserta didik yang menjadi tugas dari setiap pendidik. Hal ini didukung dengan hasil penelitian Aiman (2016) menunjukkan bahwa, penilaian sikap yang dilakukan oleh guru agama dan guru PPKn tidak cukup sebagai data untuk mengonfirmasi sikap siswa karena pelaksanaan penilaian sikap harus dilakukan secara berkesinambungan. Selain itu, terdapat keterbatasan waktu dan jumlah siswa yang terlalu banyak sehingga penilaian sikap dilaksanakan oleh semua guru mata pelajaran. 
Idealnya menurut Panduan Penilaian SMA 2017, penilaian sikap dapat dilakukan dengan tiga cara yaitu penilaian observasi, penilaian diri dan penilaian antarteman. Penilaian observasi dilakukan melalui pengamatan perilaku menggunakan jurnal yang dilaksanakan oleh guru mata pelajaran. Penilaian diri dilakukan untuk mengetahui kelebihan dan kekurangan dirinya. Penilaian antarteman dilakukan untuk mengetahui objektifitas peserta didik. Penilaian antarteman dan penilaian diri dilakukan sekurang-kurangnya satu kali dalam satu semester. Fakta di lapangan ditemukan bahwa tergolong kurang dalam melakukan penilaian sikap spiritual dan sikap sosial peserta didik

SMA Negeri 3 Singaraja, merupakan sekolah terakreditasi A dan menerapkan kurikulum 2013 yang berarti melakukan penilaian autentik. Berdasarkan hasil studi pendahuluan di SMA Negeri 3 Singaraja dengan teknik observasi, wawancara dan studi dokumen. Hasil observasi, wawancara dan studi dokumen menunjukan terdapat tiga cara penilaian sikap yaitu penilaian observasi, penilaian diri dan penilaian antarteman. Akan tetapi, guru kimia hanya melakukan penilaian observasi karena penilaian sikap dititikberatkan pada guru mata pelajaran pendidikan agama dan PPKn.

Tujuan dari penelitian ini adalah penilaian sikap sebagai dampak pengiring pembelajaran praktikum kimia, Penelitian ini termasuk jenis penelitian fenomenologi dengan pendekatan kualitatif. Teknik pengumpulan data dengan cara wawancara, observasi, dan studi dokumen. Teknik analisis data yang digunakan adalah reduksi data, penyajian data, dan penarikan kesimpulan. Uji keabsahan yang digunakan dalam penelitian ini adalah triangulasi sumber dan triangulasi metode.

\section{METODE}

Metode yang digunakan pada penelitian ini adalah fenomenologis dengan pendekatan kualitatif. Munurut Sugiyono (2011), dinyatakan bahwa penelitian kulitatif dilakukan pada kondisi yang alamiah, langsung kesumber data dan peneliti adalah sumber kunci. Penelitian ini dikategorikan pendekatan fenomenologis karena berorientasi untuk memahami, menggali dan menafsirkan arti dan peristiwa-peristiwa, dan hubungan dengan orang-orang yang biasa dalam situasi tertentu (Moleong, 2006). Lokasi penelitian di SMA Negeri 3 Singaraja yang beralamat di Jalan Pulau Natuna, Penarukan, Singaraja. Subjek penelitian ini adalah guru kimia, waka kurikulum, siswa, dan pengawas eksternal dengan teknik pengumpulan data yaitu wawancara, observasi dan melakukan studi dokumen. Teknis analisis data pada penelitian kualitatif yaitu (1) analisis sebelum di lapangan, pada tahap ini peneliti mengumpulkan data berupa hasil wawancara terhadap guru kimia yang mengajar di SMA Negeri 3 Singaraja; (2) analisis selama di lapangan tahap pertama yang dilakukan yaitu melakukan observasi, wawancara dan melakukan studi dokumen. Selanjutnya melakukan reduksi data adalah memilih hal-hal yang pokok dan memfokuskan pada hal-hal yang dianggap penting. Setelah melakukan reduksi dat adengan menggunakan pengkodean kemudian dilakukan penyajian data yaitu disusun sesuai aspek yang diteliti dihubungkan data satu dengan data lainnya. Tahap selanjutnya yaitu penarikan kesimpulan apabila kesimpulan yang disampaikan pada tahap awal telah didukung dengan bukti-bukti yang valid dan konsisten saat peneliti mengumpulkan data dilapangan; (3) analisis setelah di lapangan data-data yang telah diperoleh dari hasil studi dokumen, observasi, dan wawancara kemudian dideskripsikan. Setelah semua pengumpulan data berakhir, tahap selanjutnya adalah penarikan kesimpulan akhir, sehingga diperoleh kesimpulan dari penelitian yang dilakukan. Tahap terakhir yaitu pengujian keabsahan data untuk menguji kebasahan data dilakukan dengan teknik triangulasi sumber dan teknik triangulasi metode yang terakhir yaitu member check.

\section{HASIL DAN PEMBAHASAN}

Hasil penelitian dan pembahasan ini mengacu pada tujuan penelitian, yaitu mendeskripsikan dan menjelaskan metode guru dalam melaksanakan penilaian sikap sebagai dampak pengiring pembelajaran kimia di SMA Negeri 3 Singaraja meliputi tahap perencanaan yaitu tahap cara guru merancang penilaian sikap yang akan digunakan untuk menilai sikap siswa, tahap pelaksanaan yaitu cara guru melaksanakan penilaian dan mengimplementasikan nilai karakter pada siswa, tahap penilaian yaitu cara guru memberikan penilaian sikap setelah dilakukan dalam pembelajaran, dan tahap pengawasan yaitu tugas pengawasan.

dalam melakukan pengawasan terkait dengan penilaian sikap yang dilakukan oleh guru.

\section{a. Perencanaan Pembelajaran}

Perencanaan awal yang disiapkan oleh guru kimia sebelum mengajar di kelas adalah membuat RPP yang dibuat secara mandiri oleh guru. Proses pembuatan RPP diawali dengan melihat KI dan KD yang terdapat pada silabus kemudian dilanjutkan dengan membuat rumusan indikator. 
Indikator yang telah dibuat kemudian menjadi dasar dalam pembuatan tujuan pembelajaran. Tahap berikutnya adalah merumuskan materi ajar yang diperoleh dari buku, menentukan metode yang digunakan sesuai dengan karakteristik materi yang diajarkan, menyiapkan media pembelajaran yang akan digunakan, membuat langkah-langkah pembelajaran, membuat penilaian hasil belajar salah satu penilaian yang dibuat yaitu penilaian sikap siswa.

RPP kelas X pada topik larutan elektrolit dan nonelektrolit, reaksi reduksi dan oksidasi serta tata nama senyawa yang diteliti pada penelitian ini sebanyak 2 buah. RPP kelas XI pada topik asam dan basa yang diteliti pada penelitian ini sebanyak satu buah. Berdasarkan hasil studi dokumen yang telah dilakukan RPP kelas X sama seperti RPP kelas XI, dapat dinyatakan bahwa RPP yang dibuat oleh guru memuat identitas mata pelajaran, kompetensi dasar (KD), indikator capaian kompetensi, tujuan pembelajaran, materi ajar, metode pembelajaran, media pembelajaran, sumber belajar, kegiatan pembelajaran yang meliputi kegiatan pemdahuluan, kegiatan inti, dan penutup untuk setiap pertemuan serta menuat penilaian hasil belajar.

Pada pembelajaran berlangsung guru juga wajib untuk melakukan penilaian salah satu penilaian yaitu penilaian sikap, sehingga guru menggunakan pedoman penilaian sikap.Berdasarkan hasil studi dokumen yang telah dilakukan, pada RPP guru merencanakan penilaian sikap berupa penilaian observasi, penilaian teman sejawat, dan penilaian diri.Hal tersebut menunjukan bahwa perencanaan penilaian sikap yang tercantum pada RPP yang dibuat oleh guru sudah tergolong lengkap.

Studi dokumen berikutnya adalah pedoman penilaian sikap. Pedoman penilaian sikap yang terlampir pada RPP hanya penilaian observasi.Namun, guru merancang lembar penilaian sikap sesuai dengan format yang diberikan oleh sekolah yang menilai karakter rasa ingin tahu, jujur, disiplin, dan tanggung jawab.Setelah ditelusuri lebih mendalam melalui wawancara, diperoleh informasi bahwa guru memang tidak melampirkan penilaian teman sejawat dan penilaian diri karena penilaian tersebut kurang efektif. Kurang efektifnya penilaian teman sejawat dan penilaian diri dikarenakan siswa memberikan penilaian hanya sekedarnya saja atau tidak serius, sehingga penilaian sikap yang dilakukan tidak jujur.

RPP yang dibuat guru tidak merencanakan adanya praktikum. Berdasarkan hasil wawancara yang dilakukan, diperoleh informasi bahwa guru membenarkan tidak merencanakan praktikum pada RPP karena praktikum memerlukan waktu yang lama. Guru melakukan praktikum apabila memiliki waktu untuk melakukan praktikum dan guru sudah merancang LKS yang dipergunakan untuk praktikum Langkah-langkah praktikum yang digunakan sesuai dengan RPP pembelajaran. Menurut Wiratma (2014), pembelajaran kimia tidak bisa dilepaskan dari kegiatan praktikum, karena sebagian besar konsep dan teori kimia yang dipaparkan dalam praktikum mesti dibarengi dengan ujicoba laroratorium.

Pada saat penyusunan RPP yang dibuat oleh guru mencantumkan $\mathrm{KI}-1$ yang berkenaan dengan sikap spiritual dan KI-2 yang berkenaan dengan sikap sosial. Dalam penyusunan RPP, KI1 dan KI-2 wajib untuk dicantumkan.Menurut Permendikbud Nomor 103 Tahun 2014 yaitu rencana pelaksanaan pembelajaran (RPP) merupakan rencana pembelajaran yang dikembangkan mengacu pada silabus dengan memuat kompetensi inti yaitu kompetensi inti 1 (sikap spiritual), kompetensi inti 2 (sikap sosial), kompetensi inti 3 (pengetahuan), dan kompetensi inti 4 (keterampilan). Berdasarkan hasil studi dokumen didapatkan guru sudah mencantumkan kompetensi inti yaitu kompetensi inti 1 yang berkenaan dengan sikap spiritual dan kompetensi inti 2 yang berkenaan dengan sikap sosial.

Pada panduan penilaian Kemendikbud (2017), 18 nilai karakter tersebut dipersingkat untuk memudahkan guru dalam mengukur pencapaian sikap, maka digunakan indikator penilaian sikap yang dapat diobservasi atau diamati. Pada panduan penilaian oleh pendidik dan satuan pendidikan SMA nilai karakter yang bisa dinilai yaitu nilai religius, jujur, disiplin, tanggung jawab, toleransi, gotong royong, santun atau sopan, dan percaya diri. Akan tetapi guru hanya merancang memunculkan nilai karakter nilai religus, jujur, disiplin, kerjasama, responsive, pro-aktif dan peduli lingkungan.Setelah dilakukan wawancara lebih lanjut guru hanya mampu merancang beberapa nilai karakter karena menilai karakter siswa cukup sulit. Sulitnya menilai karakter siswa dikarenakan saat proses pembelajaran berlangsung, guru memiliki sedikit waktu dalam menilai karakter siswa. Selain itu, jumlah siswa yang cukup banyak membuat guru sulit untuk mengamati sikap siswa secara detail.

\section{b. Pelaksanaan pembelajaran}

Objek penelitian pada pelaksanaan penilaian sikap adalah pelaksanaan pembelajaran yang dilakukan oleh guru sebagai implementasi RPP yang mengacu pada kurikulum 2013.Pada kegiatan pendahuluan guru mengajarkan nilai karakter secara tidak langsung yaitu dengan datang 
tepat waktu nilai karakter yang ditanamkan yaitu disiplin. Dari kegiatan yang dilakukan oleh guru yaitu mengucapkan panganjali umat yaitu guru menanamkan sikap sopan. Setelah mengucapkan panganjali umat yaitu guru meminta ketua kelas untuk memimpin doa bersama dengan menumbuhkan sikap religius. Mengecek kehadiran siswa merupakan kegiatan yang dilakukan oleh guru dengan mengecek kehadiran guru menumbuhkan sikap disiplin kepada siswa agar tidak membolos pada saat pelajaran. Selain mengecek kehadiran guru mengecek kelengkapan siswa sebelum mulai praktikum yaitu dengan mengecek siswa membawa masker dan sarung tangan secara tidak langsung guru mengajarkan siswa untuk bertanggung jawab karena guru sudah mengingatkan siswa untuk membawa perlengkapan seperti masker dan sarung tangan pada pertemuan sebelumnya.

Saat guru memberikan motivasi belajar dan apersepsi guru memberikan pertanyaan terkait dengan pembelajaran yang sebelumnya, saat guru mengajukan pertanyaan siswa mengancungkan tangan untuk menjawab pertanyaan secara tidak langsung guru menumbuhkan rasa ingin tahu dari siswa. Pengetahuan awal siswa membuat siswa memiliki rasa ingin tahu terkait dengan materi selanjutnya.Tujuan pembelajaran praktikum disampaikan oleh guru diakhir kegiatan pendahuluan yang bertujuan untuk memfokuskan siswa belajar. Setelah menyampaikan tujuan pembelajaran praktikum guru meminta siswa untuk membentuk kelompok.Pembelajaran dengan kelompok akan menumbuhkan sikap kerjasama siswa. Hal ini sejalan dengan penelitian yang dilakukan oleh Muhlis (2018) bahwa dengan pembelajaran kelompok, siswa akan saling bekerjasama dan termotivasi untuk memahami materi pelajaran. Namun, pada kegiatan pendahuluan guru tidak menyampaikan cakupan materi dan penjelasan uraian kegiatan.

\section{- Mengamati}

Saat melakukan demonstrasi alat dan bahan, guru menumbuhkan rasa ingin tahu siswa. Pernyataan di atas didukung oleh hasil wawancara dengan siswa yang menuturkan bahwa guru menanamkan nilai karakter terkait dengan sikap rasa ingin tahu. Saat sedang meminta siswa untuk membacakan langkah kerja praktikum guru menumbuhkan sikap percaya diri. Sikap percaya diri ditunjukan melalui sikap siswa yang ingin mencoba membacakan langkah kerja praktikum.

- Menanya

Guru meminta siswa untuk menanya secara tidak langsung menumbuhkan sikap rasa ingin tahu dan kreatif.Sikap rasa ingin tahu ditunjukan dari keingintahuan siswa untuk mendapatkan jawaban terkait pertanyaan yang telah dibuat sedangkan sikap kreatif ditunjukan dari kualitas pertanyaan siswa.

- Mengumpulkan data

Siswa diminta untuk mengambil peralatan yang sebelumnya diminta untuk menggunakan masker dan sarung secara tidak langsung guru menumbuhkan sikap disiplin. Mengarahkan siswa untuk melakukan praktikum secara bergilir setiap kelomponya, dengan demikian guru menumbuhkan sikap kerjasama, jujur, kreatif, dan rasa ingin tahu. Guru mengingatkan siswa agar menjaga kebersihan selama praktikum berlangsung yaitu guru menumbuhkan sikap peduli lingkungan. Guru menanya hasil praktikum kepada siswa dan siswa menjawab terdapat perbedaan dengan demikian guru menumbukan sikap jujur serta guru menegaskan kepada siswa untuk melaporkan hasil praktikumnya dengan jujur. Dengan guru mengingatkan siswa terkait berhati-hati dalam melakukan praktikum, guru menumbuhkan sikap disiplin saat melakukan parktikum.

- Menganalisis

Pada saat menganalis data nilai karakter yang dibangun adalah sikap kerjasama, jujur, gemar membaca, dan kreatif. Sikap kerjasama ditunjukan melalui aktifitas siswa dalam mencari data. Mengingatkan siswa untuk membuat sesuai dengan hasil praktikum yang dilakukan, guru menumbuhkan sikap jujur siswa. Sikap gemar membaca ditunjukan dari membaca materi yang berkaitan dengan hasil praktikum. Sikap kreatif ditunjukan dengan kemampuan siswa dalam mengolah data sehingga siswa dapat mengaitkan materi hasil praktikum dengan materi yang dipelajari.

\section{- Mengomunikasikan}

Pada saat mengomunikasikan, nilai karakter yang dibangun adalah sikap jujur, bertanggung jawab, disiplin, percaya diri, kerjasama, dan komunikatif. Sikap jujur ditunjukkan dari pelaporan hasil praktikum sesuai dengan hasil yang didapatkan siswa. Sikap bertanggung jawab ditunjukkan dari siswa dapat menjelaskan hasil diskusi kelompok yang telah dilakukan. Sikap disiplin yaitu ditunjukkan dari siswa yang tidak presentasi serius dalam mendengarkan penjelasan teman. Sikap percaya diri ditunjukan dari keberanian dalam menyampaikan hasil diskusi kelompok. Sikap kerjasama ditunjukkan dari kelompok yang presentasi membagi tugas dalam mempresentasikan hasil diskusi kelompok. Sikap komunikatif ditunjukkan dari kemampuan siswa dalam melakukan 
presentasi. Pada tahap ini guru memberikan sedikit penekanan terhadap materi yang sedang dipraktikum.

Pada kegiatan penutup siswa diminta untuk menyimpulkan pelajaran yang telah dilakukan saat menyimpulkan guru menumbuhkan sikap percaya diri, kreatif, komunikatif dan mandiri. Memberikan tugas membuat laporan praktikum kepada siswa, guru menumbuhkan sikap bertanggungjawab, kreatif, jujur dan mandiri. Guru meminta ketua kelas untuk memimpin berdoa bersama yaitu guru menumbuhkan sikap spiritual dan diakhir pelajaran guru mengucapkan salam penutup dengan demikian guru menumbuhkan sikap sopan.

Berdasarkan hasil observasi dan wawancara yang dilakukan didapatkan hasil bahwa guru menanamkan nilai-nilai karakter secara tidak langsung. Nilai-nilai karakter yang ditanamkan oleh guru sesuai denan irisan yang terdapat pada pendidikan karakter dan softskills. Berikut ini irisan butir-butir karakter yang muncul berdasarkan analisis silabus, pendidikan karakter dan softskills.

Tabel 1. Irisan Sikap, Pendidikan Karakter dan Softskills

\begin{tabular}{lccc}
\hline $\begin{array}{c}\text { Butir-butir } \\
\text { Karakter }\end{array}$ & $\begin{array}{c}\text { Sikap } \\
\text { Spiritual } \\
\text { dan Sikap } \\
\text { Sosial }\end{array}$ & $\begin{array}{c}\text { Pendidikan } \\
\text { Karakter }\end{array}$ & Softskills \\
\hline Religius & $\sqrt{ }$ & $\sqrt{ }$ & \\
Toleran & $\sqrt{ }$ & $\sqrt{ }$ & $\sqrt{ }$ \\
Disiplin & $\sqrt{ }$ & $\sqrt{ }$ & $\sqrt{ }$ \\
Jujur & $\sqrt{ }$ & $\sqrt{ }$ & $\sqrt{ }$ \\
Kerjasama & $\sqrt{ }$ & $\sqrt{ }$ & $\sqrt{ }$ \\
Tanggung & $\sqrt{ }$ & $\sqrt{ }$ & $\sqrt{ }$ \\
Jawab & & $\sqrt{ }$ & $\sqrt{ }$ \\
Percaya Diri & $\sqrt{ }$ & $\sqrt{ }$ & $\sqrt{ }$ \\
Santun & $\sqrt{ }$ & & \\
\hline
\end{tabular}

Berdasarkan Tabel 1 melalui observasi yang dilakukan didapatkan hasil bahwa guru menanamkan nilai-nilai karakter secara tidak langsung. Nilai-nilai karakter yang ditanamkan oleh guru sesuai dengan irisan yang terdapat pada pendidikan karakter, analisis silabus dan softskills.

Hasil Penenilitian tersebut didukung oleh Fauzi (2017), yaitu upaya penguatan pendidikan karakter menjadi dasar dalam penerapan kurikulum 2013. Penerapan kurikulum 2013 ini memberikan perubahan paradigma, dimana pada hasil akhir pembelajaran siswa tidak hanya menguasai pengetahuan tetapi juga menguasai sikap dan keterampilan. Untuk membentuk karakter tersebut maka dibutuhkan tindakan pembelajaran berupa pendekatan, model, metode ataupun strategi pembelajaran yang tepat. Sehingga digagaslah penerapan model discovery learning dengan pendekatan saintifik karena model tersebut efektif dan efisien dalam menumbuhkan karakter rasa ingin tahu dan peduli sosial.

\section{c. Penilaian Sikap}

Penilaian sikap menggunakan penilaian teman sejawat dan penilaian diri kurang efektif karena penilaian yang dilakukan terkadang tidak sesuai fakta yang terdapat dilapangan. Jadi penilaian sikap dilakukan hanya berdasarkan observasi/pengamatan yang dicatat pada lembar obsevasi/pengamatan. Guru tidak melakukan penilaian teman sejawat dan penilaian diri, karena penilaian teman sejawat dan penilaian diri kurang efektif untuk dilakukan. Hal tersebut dikarena terdapat ketidak sesuaian anatara fakta yang ada dengan nilai yang tertera.Hal tersebut didukung oleh Djailani (2013), ditunjukkan bahwa kepala sekolah dan guru di sekolah unggulan yang berada di Banda Aceh menerapkan pembentukan karakter siswa dengan menggunakan strategi berikut: memberikan pemahaman tentang karakter atau kepribadian siswa, mengembangkan budaya Islam di sekolah, pembentukan karakter melalui forum khusus, patut dicontoh, sanksi bagi siswa yang melanggar.

Penilaian sikap di luar kelas tidak melakukan penilaian sikap akan tepapi apabila melihat perilaku siswa yang menonjol maka akan dicatat. Hal tersebut dikarenakan pada saat diluar jam pelajaran yang menilai sikap siswa yaitu guru BK atau pengawas yang ditunjuk oleh kepala sekolah.Terkait dengan penilaian sikap semua guru wajib untuk menyetorkan nilai kepada wali kelas. Guru agama dan guru PKn memang mengajarkan secara langsung terkait dengan nilai karakter, tetapi guru lain tetap melaporkannya.

Pada saat melakukan penilaian sikap terdapat kesulitan yaitu yaitu saat mengedarkan untuk penilaian teman sejawat dan penilaian diri banyak hasilnya tidak sesuai dengan fakta serta 
mengaalami kesulitan dalam menilai sikap karena penialian yang seringkali berubah-ubah. Cara untuk mengantisipasi kesulitan yang dihadapi yaitu menggunakan penilaian berdasarkan pengamatan kemudian dilakukan pengecekan kembali.

Dalam menilai sikap siswa, guru menggunakan jurnal dalam menilai sikap siswa yang menonjol kurang baik maupun sangat baik. Siswa yang bersikap menonjol kurang baik akan diberikan hukuman dan siswa yang bersikap menonjol sangat baik akan diberikan pujian. Guru tidak melakukan penilaian diri sendiri dan penilaian teman sejawat karena hasil observasi di jurnal dengan hasil penilaian diri dan penilaian teman sejawat tidak cocok, seringkali siswa hanya menilai dirinya baik dan menilai teman sejawat baik.

Berdasarkan hal tersebut, untuk memunculkan nilai sikap di rapot maka digunakan modus nilai yang sering muncul yang ditentukan oleh guru BK, agama, dan PKn sedangkan mata pelajaran lain sebagai penunjang. Pemberian predikat B dengan deskripsi sudah konsisten dapat dimaknai bahwa siswa sudah mengerti, memahami, dan melakukannya secara terus menerus dengan baik yang berpatokan dengan tata tertib sekolah, predikat A dengan deskripsi amat baik memiliki makna bahwa siswa mampu mengerti, memahami, dan melakukannya dengan sungguhsungguh dan rutin tanpa paksaan yang berasal dari niat sendiri tanpa disuruh, predikat $C$ dengan dekripsi cukup memiliki makna bahwa siswa sudah melakukan namun tidak memahami dengan baik yang dia lakukan.

Dalam hal tersebut dapat disimpulkan bahwa penilaian sikap dalam pembelajaran kimia menggunakan observasi dengan menggunakan jurnal sedangkan penilaian teman sejawat dan penilaian diri sendiri tidak dilakukan karena hasil melalui pengamatan dengan hasil penilaian diri dan penilaian antar teman tidak sesuai. Apabila dalam jurnal tidak ada nama siswa yang tercatat maka sikap siswa diberi nilai $B$, sedangkan bila menonjol sangat baik atau kurang maka akan diberi nilai $\mathrm{A}$ atau $\mathrm{C}$, nilai sikap dari guru kimia lalu diserahkan kepada wali kelas, dari wali kelas menyetor jurnal kepada guru BK, agama, dan PKn untuk diolah sehingga muncul nilai sikap siswa. Setelah disimpulkan, nilai sikap siswa diserahkan ke wali kelas masing-masing untuk dibuatkan deskrpsi. Hasil penelitian sejalan denganAiman (2016), bahwa penilaian sikap yang dilakukan oleh guru agama dan guru PKn tidak cukup sebagai data untuk mengonfirmasi sikap siswa karena pelaksanaan penilaian sikap harus dilakukan secara berkesinambungan namun terdapat keterbatasan waktu dan jumlah siswa yang terlalu banyak sehingga penilaian sikap spiritual dan sikap sosial dilaksanakan oleh semua guru pengampu mata pelajaran karena guru harus mengetahui perkembangan sikap spiritual dan sikap sosial siswa sehingga antara guru agama, guru PKn, dengan guru pengampu mata pelajaran lain terdapat kerjasama yang baik dalam menangani siswa baik siswa bermasalah atau siswa yang belum tuntas pada pembiasaan pada sikap sosial dan sikap spiritual, penilaian sikap tidak hanya sekadar kewajiban guru dalam menilai, namun sikap sudah menjadi ruh dalam jiwa siswa.

\section{d. Pengawasan Penilaian Sikap}

Pada saat pelaksanaan pengawasan terdapat beberapa keluhan dari guru terkait dengan penilaian sikap terutama pada awal pelaksanaan kurikulum 2013 mengenai penilaian sikap yang berubah-ubah. Terdapat perbedaan yang signifitas dari hasil penilaian jurnal yang dilakukan guru dengan penilaian yang dilakukan oleh siswa melalui penilaian diri dan penilaian teman sejawat. Hal tersebut dibenarkan oleh pengawas sekolah dari UPT yaitu terdapat beberapa keluhan dari guru terkait dengan penilaian sikap yang berubah-ubah. Terkait dengan keluhan dari guru terkait dengan penilaian sikap wakil kepala sekolah dan pengawas sekolah mengatasinyamaka dilakukan metode khusus yaitu dengan mengadakan workshop untuk membantu guru dalam melakukan penilaian sikap. Melalui workshop guru diberikan pelatihan tentang penilaian yang terbaru untuk menghindari kesalahan saat melakukan penilaian. Hasil penelitian didukung oleh Sasmito (2015), Salah satu kompetensi utama dari Kompetensi seorang supervisi adalah membimbing para guru dalam menentukan aspek-aspek yang penting dinilai untuk setiap bidang pengembangan mata pelajaran yang termasuk dalam rumpunnya. Bimbingan oleh pengawas sekolah terhadap guru dalam menyusun program pembelajaran sesuai dengan standar pengetahuan, sikap dan keterampilan.

\section{SIMPULAN DAN SARAN}

Dari perencanaan guru merencanakan penilaian sikap terdapat pada RPP guru. Pada pelaksanaan guru menanamkan nilai karakter tetapi guru kurang menyadari melakukan penanaman nilai karakter. Pada penilain sikap guru hanya melakukan penilaian jurnal berdasarkan pengamatan dan lembar penilaian. Pada penilaian jurnal guru hanya mengati sikap siswa yang 
menonjol sikap sangat baik dan kurang baik, sedangkan penilaian menggunakan lembaran hanya menilai sikap jujur, tanggung jawan, disiplin, dan rasa ingin tahu. Terdapat keluhan dari guru terkait dengan penilaian sikap yang sering berubah dan penilaian sikap berdasarkan penilaian teman sejawat dan penilaian diri kurang efektif. Dalam mengantisipasi hal tersebut pengawas melakukan workshop gar tidak terjadi kesalah pada penilaian sikap.

Kepada peneliti selanjutnya disarankan unutk meneliti lebih lanjut terkait dengan penilaian sikap yang dilakukan oleh guru dan pembuatan penilaian sikap berdasarkan standar baru yang ada.

\section{DAFTAR RUJUKAN}

Adawiah, R. 2016. Profeseonalitas Guru dan Pendidikan Karakter (Kajian Emperis di SDN Kabupaten Balangan). Jurnal Pendidikan Kewarganegaraan. 6(1):939-946.

Aiman, U. 2016. Evaluasi Pelaksanaan Penilaian Autentik Kurikulum 2013; Studi Kasus di Madrasah Ibtidaiyah Negeri Tempel Sleman Yogyakarta. Jurnal Pendidikan Madrasah. 1(1):115-122.

Fauzi, A.R, dkk. 2017. Penguatan Karakter Rasa Ingin Tahu dan Peduli Sosial Melalui Discovery Learning. Jurnal Teori dan Praksis Pembelajaran IPS. 2(2):28-36.

Kemendikbud. 2017. Panduan Penilaian Oleh Pendidik dan Satuan Pendidikan untuk Sekolah Menengah Atas. Jakarta: Kementrian Pendidikan dan Kebudayaan.

Kemendiknas. 2010. Pedoman SekolahPengembangan Pendidikan Budaya dan Karakter Bangsa. Jakarta:Kementrian Pendidikan Nasional.

Mariati, M.R dan Riska, C.N. 2012. Penerapan Model Apprentice Training yang Berwawasan Konstruktivisme dalam Upaya Meningkatkan Kualitas Pembelajaran Kimia. Jurnal Pendidikan Serambi IImu. 13(2):111-124.

Moleong, L.J. 2006. Metode Penelitian Kualitatif. Bandung: PT Remaja Rosdakarya Offset.

Muhlis. 2018. Pengaruh Pembelajaran Kooperatif Terhadap Motivasi dan Hasil Belajar Siswa Pada Materi Sistem Koloid SMAN 4 Bantimurung Maros. Jurnal IImu Pendidikan, Keguruan, dan Pembelajaran. 2(1): 12-24.

Nufus, S.H, dkk. 2017. Pengembangan Instrumen Penilaian Sikap Berbasis Kurikulum 2013 pada Pembelajaran Kimia SMA.Jurnal Pendidikan Sains Indonesia. 05(01):44-51.

Permendikbud RI Nomor 20 Tahun 2018 Tentang Penguatan Pendidikan Karakter.

Permendikbud RI Nomor 22 Tahun 2016 Tentang Standar Proses Pendidikan Dasar dan Menengah.

Permendikbud RI Nomor 23 Tahun 2016 Tentang Standar Penilaian Pendidikan Dasar dan Menengah.

Permendikbud RI Nomor 103 Tahun 2014 Tentang Pembelajaran pada Pendidikan Dasar dan Menengah.

Permendikbud RI Nomor 81A Tahun 2013 tentang Implementasi Kurikulum.

Perpres RI Nomor 87 Tahun 2017 tentang Penguatan Pendidikan Karakter.

Ratnawati, Dianna. 2016. Kontribusi Pendidikan Karakter dan Lingkungan Keluarga terhadap Soft Skills Siswa SMK 1(1): 23-32.

Sasmito, M.A. 2015. Kontrubusi Pengawas Sekolah Terhadap Pemenuhan Standar Nasional Pendidikan. Journal of EST, 1(2):30-45.

Sugiyono. 2011. Metode Penelitian Kuantitatif, Kualitatif dan R\&D. Bandung: Alfabeta.

Sugiyono. 2014. Metode Penelitian Pendidikan Kuantitatif, Kualitatif, dan R\&D. Bandung: Alfabeta. 
Sugiyono. 2015. Metode Penelitian Pendidikan (Pendekatan Kuantitatif, Kualitatif dan R\&D). Bandung: CV Alfabeta.

Wiratma, I.G.L. 2013. Pengelolaan Pembelajaran Kimia pada SMAN 1 Singaraja dan SMAN 1 Gianyar: Dekontruksi Implementasi Standar Proses. Disertasi (Tidak diterbitkan). Program Studi Kajian Budaya, Program Pascasarjana Universitas Udayana. 